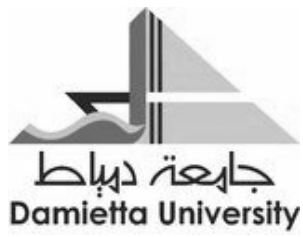

Damietta University

Faculty of Arts

\title{
Ahad Ha'am's Cultural Zionism as a Global
}

\section{Phenomenon.}

By

Shaimaa Mohamed Hassanin 


\section{Ahad Ha'am's Cultural Zionism as a Global Phenomenon.}

Cultural Zionism is a type of Zionism that values and appreciates Jewish culture, history and language. Asher Ginzberg (1856-1927), who is known by his Hebrew name as Ahad Ha'am, one of the people, is the founder of cultural Zionism. He noticed that Jews' problems were imbedded in Judaism, so he planned to revitalize the idea of religion in the mind of every Jew. He also discovered that the solution of the problem was in the idea of nationalism that could connect Jews to Judaism by figuring out fresh ideas.

Ha'am was born in Skvyra, Russia in 1856 to Hasidic parents. When he was a child, he started to learn Russian alphabets and philosophy. Later, Ha'am's family moved to Kiev where his father assigned him private teachers, because he discovered that his son had a talent in writing. Though Ha'am excelled in his study, he did not forget his Jewish heritage and teachings of Judaism. In his youth, Ha'am was much influenced by Leon Pinsker, the founder and leader of Hovevei Zion, the lovers of Zion movement. This movement encouraged many Jews to settle in Palestine, and it successfully planned for the first Jewish immigration, Aliyah, in 1882. After gaining some experience through the movement, Ha'am travelled to Palestine to closely see the situation. He wrote many reports and essays explaining the situation of the Jewish settlement there, and he warned against the anger of the indigenous inhabitants by declaring: 
We must surely learn, from both our past and present history, how careful we must be not to provoke the anger of the native people by doing them wrong, how we should be cautious in dealings with a [sic] foreign people among whom we returned to live, to handle these people with love and respect and, needless to say, with justice and good judgment. (15)

Ha'am recognized the efforts that should be exerted to create the spiritual centre in Palestine. He realized that the bases of this centre should be built on the reviving of Hebrew. Most of the Jews used to speak Yiddish as their official language. Later, the use of Hebrew has been adopted by many Jewish organizations in Palestine as a force that could create the Jewish cultural centre. The place and language are very important, because they are inseparable parts in the process of creating a new culture. Ha'am points out that Hebrew could help value Jewish ideas and solve Jewish questions in different times:

The immediate step towards the solution of the Jewish question is the return of the Jews to their own "spiritual possessions "-to the Hebrew language and literature. Only by learning to understand and to value the ideas for which they have stood in the past can they [sic] become capable of desiring to stand for something in the present and the future. (35)

Jewish ambition and self-reliance made Ha'am believe that studied plans and organized preparation could create what Jews had ever dreamed of. He called for Jewish settlement in Palestine as a means of gaining international support for Jewish culture. In Palestine, he demanded the Jewish groups to dedicate themselves to the mission of building a Jewish culture based on pride and courage. Also, he believed that new society could plant the seeds of a Jewish cultural centre in the heart of every Jew. 
Ha'am was much interested in Jewish problems in Diasporas and in Palestine. According to him, the Jewish question falls into two forms: one in the East and the other in the West. In the West, the Jewish question has succeeded in making the Jews lose their identity. Then, it has succeeded again in exposing them to anti-Semitism, a fact that has made them go back to their Jewish identity. But on their way back, they have found that the Jewish world has been no more than a part of their culture. So, they have aspired to create a Jewish state, where they can get their essentials in life without being afraid of losing their Jewish identity again. At least, the idea of having a Jewish homeland would cure Jews from the feeling of denial, loneliness and disappointment.

The Eastern Jews have a twofold problem: the physical and cultural. The problems have begun when the Herzelain wave has failed to solve any of the Jews' cultural and spiritual problems. With regard to the physical aspect, Ha'am found out that there was an impossibility of evacuating Europe and other countries of Jews. So, the Jewish state would only include a section of Jews in Palestine. Eventually, solving the physical problem would mainly depend on the economic conditions and cultural levels of different Diasporas.

Consequently, Ha'am discovered that the main cultural problem could be solved by resorting to Jewish nationalism and identity. He claimed that the Jewish religion, despite its stagnation, was more appropriate than any other religion to the cultural centre. Judaism has emphasized the importance of collective and rational minds, which could build a cultural centre. Through the update process of religion, Ha'am mixed the spirit and body to create a full body of the Jewish state. For him, the only possible way to unite 
body and soul is the revival of the Hebrew spirit through the creation of a concrete Jewish life in Palestine.

In the middle of the nineteenth century, there was a general trend towards Jewish nationalism that began to prevail among Jews in Eastern Europe. Also, Hebrew was no longer the sacred tongue of Jews, but it has become the language of secular Jewish literature. Ha'am contributed to this trend and added secular pigments to religious concepts such as: 'God chosen people', 'super nation', 'superman' and 'superior nation'. Of course, these terms have encouraged Jews to create their own dream. Ha'am notes: If we agree, then, that the Superman is the goal of all things, we must needs agree also that an essential condition of the attainment of this goal is the Supernation: that is to say, there must be a single nation better adapted than other nations, by virtue of its inherent characteristics, to moral development, and ordering its whole life in accordance with a moral law which stands higher than the common type. This nation will then serve as the soil essentially and supremely fitted to produce that fairest of all fruits - the Superman. (228)

Based on secular pigments and religious concepts, Ha'am put his own theory of cultural Zionism, which aimed to promote traditional Jewish culture in order to co-exist with modern ages. This could be accomplished within the framework of Jewish nationalism. Therefore, Ha'am suggested creating a cultural centre in Palestine before the establishment of a Jewish state. Such a centre could consolidate the Jewish identity that should keep up with modern concepts. In Palestine, Jews could settle and work in various branches of life such as: farming, manual works and industry. By time, this natural and cultural centre could become a centre of national spirit. Also, it could be developed to the highest degree of perfection. 
According to Ha'am, the solution of Jews' problems could be found in the efforts of Jewish groups existing in different areas around the world. He saw these groups as the seeds of his cultural centre. In order to create such a centre, Ha'am had to solve two main problems facing his program. First, his program never mentioned the mechanisms of establishing the cultural centre. Also, it never raised the issue of political centre but it left these matters vague. It probably left these things to the advocates of practical Zionism that took care of such procedures, such as: expropriation of the land and expulsion of its inhabitants. Second, Ha'am raised the problem of rejecting all existing Jewish cultures, both Yiddish in Eastern Europe or Sephardic in eastern countries. But, he was not much worried about these problems, and he put what he has called Jewish culture in Palestine as an alternative to all these kinds of cultures.

After a while, Ha'am joined the field of Zionist activity, and he started by being the leader and thinker of Hibbat Zion, the lovers of Zion. Soon, he criticized the policy of this group, because it was calling for settlement in Palestine as a first step to create his cultural centre. He refused such an attitude and started to search for other suitable procedures, which could guarantee the right way of his cultural Zionism. He expresses his opinion about the settlement in Palestine in an essay called 'This is not the way' or 'The wrong way:

It [cultural Zionism] needs not an independent State, but only the creation in its native land of conditions favorable to its development: a good-sized settlement of Jews working without hindrance in every branch of culture, from agriculture and handicrafts to science and literature. This Jewish settlement, which will be a gradual growth, will become in course of time the centre of the nation. 
The solidarity of Jews in a cultural centre has been seen as an essential part in the process of establishing a Jewish state. If Jews' presence has been impossible without the state, the presence of a small state would have been impossible without Jews from Diasporas. So, there have been two centers of Judaism, the cultural centre in the Jewish state, Palestine, and Jewish minorities in Diasporas. These two centers have opened Ha'am's eyes to clearly see the problems through the eyes of Jews in Palestine and outside it. He emphasized the importance of the spiritual and physical centers, because through the dualism of soul and body, unity could take place:

At the outset of any inquiry into the nature and functions of man, we are faced with the apparent dualism of body and soul. For the philosopher this dualism is something illogical, and therefore unbearable: he is driven to seek for some single reality to which the two elements can be referred, be that unity matter or spirit or something which is neither. (23)

According to Ha'am, Jewish life in Diasporas and exile should be a temporary stage, because it could separate them from 'their land' and religion. In fact, the efforts of the domestic Jews should focus on using Jews in Diasporas for the benefit of the cultural centre. The continual conflict between Jews in Palestine and Diasporas could expose Jewish society to contradictions which could stand as an obstacle in the way of creating a harmonious Jewish society. Thus, Jews should be careful of creating two opposing powers inside and outside Palestine.

According to Ha'am, the temporary stage had to be short; otherwise if it was prolonged, it could gradually weaken the Jewish presence in the world. New patterns of Jews could appear, and they could lead to the division of Jews into two different categories: internal and external. Also, the temporary stage would affect the Jewish 
presence and contribution in Diasporas. So, the solution would be in a cultural centre tobe followed by a Jewish state as Ha'am explains, "The return to Palestine must precede as well as follow the restoration of Jewish culture to its proper place in the lives of Jews in other lands." (37)

In the Jewish state, according to Ha'am, there was no place for any problems except the spiritual ones. The advocates of cultural Zionism did not focus on the political or economic problems of the Jews. They left such problems to politicians like Herzl and other Zionists. They mostly focused on the problems of identity, national language and the quality of Jewish heritage. They cared much about the cultural projects, the united awareness of Jews and the relationship between Jews and their state-to-be.

Ha'am's hesitation, with respect to establishing a Zionist state, did not last for long; however, he encouraged the idea of transferring surplus Jews from Eastern Europe to Palestine. Though the massacres committed against Arabs caused him some worries, he continued to support the Zionist project till the end. After settling in Palestine, he did not react against the crimes committed against Arabs. He expresses his opinion in an essay called "Justice and Mercy", "If a time comes when our people in Palestine develop so that, in small or great measure, they push out the native inhabitants, these will not give up their place easily." (49)

Ha'am predicted that the Zionist state would form a centre that could help Jews retain their identity and face the attacks of their "Arab enemies". However, the centre did not offer much support to Jews around the world. For example, American Jews have formed their own identity and enjoyed their lives without referring to the Zionist state. Zionism as a whole has claimed its ability to establish a state, which could protect its 
members from the attacks of other cultures, but it has showed its inability to do that. In fact, Ha'am records the younger Jewish generations' inability to speak Hebrew, the national language of Jews: "The younger generation, born in America and educated in American schools, speaks English and does not understand Hebrew." (282)

For a long time, the mission of Jews has constantly been troubling Jewish thinkers in Diasporas to drive them question the mission of Israel among other nations. Ha'am referred to some Jewish scholars, who could add some aspects of modernism to Jewish life, such as: Chaim Weizmann and Leon Pinsker. Weizmann and Pinsker have recognized that the message of 'God Chosen People' has been spreading the good among people. According to them, Jews should seek happiness for the entire world: when a Jew values a community as he does his own life and advocates its happiness, he will find satisfaction and no longer feel the bitterness of his individual existence.

Nevertheless, Ha'am rejected their ideas and insisted that the message of his own people was to perform their duty without giving any regard to the world outside them. This, according to him, was an end in itself rather than a means of creating a happy world. According to him, if Jews are to perform their 'mission' in life, they must work out their ideals in their own life. In other words, he urged Jews to feel the happiness inside them first before transferring it to others. Ha'am mentions the mission of Jews and their pursuit of happiness:

It is enough to point out that the Jewish people as a whole has always interpreted its "mission" simply as the performance of its own duties, without regard to the external world, and has regarded its election, from the earliest times to the present day, as the end of all else, 
and not as a means to the happiness of the rest of the world. (230-1)

As the father of cultural Zionism, Ha'am decided to use the philosophers' opinions as propaganda to his philosophical attitude. This propaganda could attract more Jews to join the movement. He counted on the opinions of Nietzsche and agreed with some of his philosophical ideas and opposed others. He felt that Nietzsche did not understand the nature of Jewish rights and mixed up Judaism with Christianity. According to Ha'am, Jewish philosophers and thinkers would discover that there was a need to develop Nietzsche's ideas about Judaism. The great part of Nietzsche's philosophy has existed in Judaism itself for many centuries. Ha'am introduces his ideas about Nietzsche in his essay, 'The Trans-valuation of Values':

Nietzsche, as a German, may be pardoned for having failed to understand Judaism, and having confused it with another doctrine, which sprang out of it and went off on another track. But his Jewish disciples ought to know that Judaism has never based itself on mercy alone, and has never made its Superman subordinate to the mass of men. (226)

Nietzsche roused a large section of the youth of Europe to enthusiasm and captured many young Jews. He asked young Jews to deeply believe in themselves, because they are the strongest and purest race living in Europe; they know how to succeed even under the worst conditions. According to him, Jews should be on top of the human chain, because they are invincible super humans who could achieve miracles.

In general, Nietzsche had a mutual impact on Jewish religious thought and cultural Zionism, and he appeared to be a defender of Jews and Judaism. For instance, he rejected anti-Semitism and considered it another form of slaves' rebellions against 
modern man. He was an admirer of the unethical and conceivable style of the Old Testament, which did not conclude any competency or compromise. In many of his writings, he praised Jews more than the Germans, claiming that Jews have the tenacity and creativity that would enable them to re-evaluate values. According to him, Jews have brought civilization and modernization to the whole world:

The Jews have brought off that miraculous feat of an inversion of values, thanks to which life on earth has acquired a novel and dangerous attraction for a couple of millennia. ... Their prophets...were the first to use the word 'world' as a term of contempt. This inversion of values...constitutes the significance of the Jewish people: they mark the beginning of the slave rebellion in morals.

Depending on Nietzsche's moral law, Ha'am started to place Jews in higher ranks. He raised them to the rank of prophets and believed in the potential moral supremacy of 'the People of Israel'. Such a Nietzscheanism could function as an inspiring, even monumental model for Ha'am and other cultural Zionists. Thus, Ha'am was grateful to Nietzsche for legitimizing the moral law of Jews, which has given Jews priority to control the ethics of the world. Ha'am explains this issue in his essay "The Trans-Valuation of Values":

The Prophets no doubt gave utterance to the hope that Judaism would exert an influence for good on the moral condition of the other nations; but their idea was that this result would follow naturally from the existence among the Jews of the highest type of morality, not that the Jews existed solely for the purpose of striving to exert this influence. (231) 
Cultural Zionism did not stay much in papers, or in the minds of its founders. It took a different level of actual work by establishing new Jewish schools, which depended on the principles of cultural Zionism. In the nineties of the nineteenth century, preliminary improved-schools started to emerge and showed a profound impact of Zionist ideology. Their curricula combined religious and secular materials. Students were taught that Hebrew was not a sacred language, but a national one which was used in various areas of life. Also, they were taught about the history of Jews and the geography of Eretz Yisrae/'the land of Israel'. They were interested in the true expression of Jewish origin and the Old Testament which, unlike the Talmud, was written before their dispersion. In his essay "the spiritual revival", Ha'am highlights the difference between traditional and improved education and their importance:

The duty of Zionists in the sphere of education is not confined to schools of the" enlightened" type. We must remember that, side by side with the "improved" education of to-day, we have also the old traditional system, which is no doubt losing ground every year, but is still strong, is struggling hard for its existence, and will undoubtedly play an important part in our national life for many years to come, influencing by its method and its spirit the education and up building of tens of thousands of Jewish children. (301)

The establishments of Zionist improved-schools were linked to the revival of Hebrew. Ha'am asked the staff of these schools to spread the Zionist ideology in Hebrew to encourage children learn their national language well. Also, evening classes were established to teach Hebrew to Jews of different ages. The group of 'the lovers of Zion' supervised these schools and played an important role in recruiting some Talmudic school 
graduates to teach in them. Ha'am mentions the importance of these schools and the essential work of their teachers in his essay 'the spiritual revival':

Their teachers show them how to use this force [Hebrew] for their own ends, in order to reveal their own spirit; and so the self-effacement ceases, and the Imitation, turned into the channel of competition, gives added strength to the Hebrew self-consciousness. (118)

Jewish schools had enlightened many Jews to see literature as the basis of establishing a Jewish cultural centre. Zionist literature in its first stages was didactic and romantic. Moshe Smilansky, a Zionist author, depicted his admiration of Palestinians' traditions and nomadic customs. He even retrieved characters from the Old Testament to the minds of Jews. In a short story written in 1892, Smilansky portrays a Jewish child, who has been taught by an Arab how to train his body on different climates: heat, frost, flood and draught. After a while, he turns against Arabs and declares that a Jewish child should not learn from Arabs, because of their ignorant and superstitious nature:

Let us not be familiar with the Arab fellahin [peasants] lest our children adopt their ways and learn from their ugly deeds. Let all those who are loyal to the Torah avoid ugliness and that which resembles it and keep their distance from the fellahin and their base attributes. (qtd in Masalha 7)

In its early stages, Hebrew literature was classified into two categories: religious that was represented by Torah and Talmud, and intellectual that was represented by political, social and economic visions about the reality of Jewish future. These visions clearly emerged in the first Zionist congress held in Basel, Switzerland, in 1897 and classified Jewish literature into four kinds. First, Jewish literature whose roots were extended to Torah and Talmud, was divided into two parts: the old Jewish literature and 
modern literature. Both kinds sometimes depended on one or two Jewish languages,

Yiddish and Ladino.

Second, Zionist literature that was formed after the Protestant movement in Europe in the sixteenth century was controlled by the soul of Zionist ideology. There was no common language for this kind of literature as it can be English, French or Hebrew. Also, it was necessary to be written for only Jews. For example, there were Zionist literary works for European Christians, like: Danie/ Deronda by George Eliot in 1876.

Third, Hebrew literature which was written in Hebrew and followed the Protestant movement in Europe is geographically divided into two categories: Palestinian, which was written before the existence of the Zionist entity, and Israeli that was written in Palestine after 1948. Fourth, Israeli literature which was restricted to the borders of Israel included the various branches of literature: Jewish, Zionist and Hebrew. Also, it was written by Jewish writers in Modern Hebrew following the Zionist identity.

One of the most extreme and funniest examples of early Zionist literature is a play by Arich Orlov, published in Eretz Acheret. It is about a group of pioneer settlers from the second Aliyah living in a kibbutz. The heroine is the Zionist settler, Naomi, who refuses to love her own Jewish colleague and prefers an Arab peddler called Ali. When a Jew kills an Arab, Ali kills him to avenge his friend. But, Ali's behavior does not change Naomi's love for him. The play ends with a stormy monologue, where Naomi addresses her Zionist consort, " My soul despises you civilized worms. I have learned something from the wild Arab; I have learned these words; "God is generous." (qtd. in Ha'am 30)

The occasional problems of any minorities in large countries were the main concern of many writers and novelists. Of course, the eternal battle between the good and 
the evil became an active catalyst in most Jewish novels and stories. So, Zionist writers figured out that these kinds of stories attract many readers, because they reveal the realistic problems of Jews in Diasporas. However, the backward Arab formed an important image in Zionist literature. Ha'am noticed that Zionist settlers treated Arabs with contempt and cruelty as if they are 'desert savages and donkeys'. Many Zionist thinkers warned Jews against living beside Arab peasants because they are dirty, ignorant and controlled by their myths. However, Ha'am warned Jews against their cruel treatment of Arabs. He writes about the ideal dealing with indigenous people:

The Jewish settlers treat the Arabs with hostility and cruelty, trespass unjustly, beat them shamelessly for no sufficient reason, and even take pride in doing so. The Jews were slaves in the land of their Exile, and suddenly they found themselves with unlimited freedom, wild freedom that ONLY exists in a land like Turkey. This sudden change has produced in their hearts an inclination towards repressive tyranny, as always happens when slave rules. We are used to thinking of the Arabs as primitive men of the desert, as a donkeylike nation that neither sees nor understands what is going around it. (104)

Literature with its themes has been the main concern of cultural Zionism with its spiritual hegemony. Ha'am realized that culture and literature can affect generations, while politics can erase nations. So, he put some principles of cultural Zionism that can be easily followed by Jewish scholars. In his way of developing his new trend, Ha'am used every possible way to reconstitute Jewish people. For him, cultural Zionism is not an ideology of refuge, but a long-range process to reunite Jews. 
Leon Uris (1924-2003), as one of Jewish scholars, adopts the main principles of cultural Zionism principles. He adds his own version after realizing that time can change minds. So, he modernizes his ideas to cope up with new ones. Through Exodus and The Haj, Uris dedicates himself to write Jewish history, using the main principles of cultural Zionism. He asserts the unity of Jewish people around the world, considering Israel the birth place of their heritage. He considers Israel a place where any Jew can create his own life based on Jewish history, culture and religion more than any other place in the world.

Virtually, from the birth of organized cultural Zionism at the end of the nineteenth century, cultural Zionists were keenly aware of the value of publicity. The movement founder, Ha'am, devoted a considerable portion of his work towards creating a dignified Jewish appearance that would impress Jews and non-Jews. One telling example in this regard is Leon Uris's connection to cultural Zionism. During the interwar period, the famous novelist had a worldwide impact on public opinion through his novels, Exodus and The Haj. Throughout writing his novels, Uris remained in control of what he wanted to do. For him, it was very easy to direct the effects of a cultural component toward a main subject and a complicated issue that was widely popular. Basically, Exodus and The Haj have been related to Jewish heritage and culture. At the time of their publication, there was a sort of Jewish pride and self-awareness among Diaspora Jews, because Uris closely touched their problems and answered many Jewish questions about Jewish culture.

In his first step towards cultural Zionism, Uris concentrated on Hebrew as an official language of Jews. Reviving Hebrew was a major and necessary theme for all Jews 
around the world, not only in Israel. While Herzl chose German to be the official language of Jews, Ha'am asserted using Hebrew as the national language of all Jews. Ha'am played an important role in reviving Hebrew and Jewish culture, and he tried to make a link between the proposed Jewish state and Hebrew culture. In his essay 'spiritual revival', he notes:

Hebrew has been our language ever since we came into existence; and Hebrew alone is linked to us inseparably and eternally as part of our being. We are therefore justified in concluding that Hebrew has been, is, and will always be, our national language; that our national literature, throughout all time, is the literature written in Hebrew. (284)

In modern ages, language has been an obstacle in the way of many fiction novelists. Being an American writer, Uris has been obliged to write in English, because it is an international language. Through using English, he can gain international support and sympathy. It can carry his idea and guarantee success all over the world. In Exodus, Uris makes his characters speak Hebrew instead of Yiddish, considering the latter a language of ghettoes, which should be erased. For him, a new stage in Jews' lives shall take place by using the language of their nation. In Palestine, Barak Ben Canaan says to his bride, Sarah:

If we are to think like a nation, we had better speak like a nation. We do. Yiddish is our language. Yiddish is the language of exiles. Yiddish is the language of the ghetto. Hebrew is the language of all the Jews. (Exodus 252)

In The Haj, Uris exerts less effort, because readers become more comfortable with Hebrew. He uses an Arab voice this time, Ishmael whose friends live in Shemesh, a nearby kibbutz. When Ishmael enters the kibbutz, he becomes aware of Jews' traditions 
and language. Hence, he realizes the importance of Hebrew to Jews. Again, Uris introduces Hebrew as the official language of new Jewish nation through Ishmael in:

The Jews spoke their own language, called Hebrew. We spoke Arabic, of course, so when we had to deal with Jews we almost always did it in English. Neither we nor the Jews like speaking English because the British ruled the country. However, so many signs and so much business was done in English that all of us knew a little of it. (The Haj 151)

Consequently, Hebraization of surnames starts to take place among Jews in Palestine, because a Hebrew name can provide a feeling of belonging to the new state. According to the main principles of cultural Zionism, Jews should be spiritually and physically connected to the land of Israel. Of course, the physical matter can be achieved by immigrating to the 'Promised land' and the religious one may be achieved by using Hebrew and taking Hebrew names. Historically, Jews do not have permanent family surnames, because they have regularly changed their names due to constant moving. For example: Ahad Ha'am himself has a pen name, Asher Ginsberg, and Uris's family has a Hebrew surname, Yerushalmi, meaning 'man of Jerusalem.' Many Jewish immigrants have changed their names to Hebrew ones to erase the consequences of exile. Many Jews have used Hebrew patronymic names that include: Ben and Bent, meaning son and daughter. In Exodus, Jossi and Yakov Rabinsky change their names to Barak and Akiva Ben Canaan to feel spiritually and physically connected to the land of Canaan. In Exodus, Barak asks his wife, Sarah, to call him Barak instead of Jossie:

I beg your pardon, Jossi said. "There is no one in this house by the name of Jossi. If you happen to be speaking to me," he continued, "my name is Barak. Barak Ben Canaan." "Barak Ben Canaan!" (Exodus 257) 
While focusing on Jewish characters in Exodus, Uris pays much attention to Arab ones in The Haj. The main Jewish character, Gideon Asch, is a Hebrew name that indicates an offensive Haganah operation that occurred at the closing years of the British mandate in Palestine. Its main purpose is to clear the surrounding villages from Bedouins to establish new kibbutz for Jews. Gideon Asch emerges as a man of peace who comes to modernize a region that used to 'be a dirty swamp' for centuries. In spite of carrying no weapons, Gideon Asch is a fighter, a hero, Shomer who is able to defend the peaceful Jewish settlements. In The Haj, Uris displays his heroic image "Gideon Asch had not ridden into Tabah simply out of nowhere. He, too, was a long-standing partner in the history of modern Palestine." (The Haj 33)

The atmosphere is not different in The Haj, as Uris uses Arab symbolic names, like: Ibrahim, his son Ishmael and his wife Hagar in a combination that forms the story of Ibrahim and the sacrifice. But Ishmael, the obeying son of Ibrahim and Hagar, becomes Uris's outcast whose western formation rejects "the weirdness" of his own people. Unable to reconcile himself with his family, folks and religion, he suffers from a severe internal struggle.

Through Hebrew and symbolic names, Uris uses some of the main aspects of cultural Zionism. But the culmination of these aspects becomes vital when he values the identical relationship between Zionism and Judaism. In Exodus and The Haj, he shows a noticeable interest in Zionism and makes parity between it and Judaism. In the beginning of the twentieth century, Zionism took over Jewish faith to a great extent, because Judaism lost its domination over Jews for its inability of bringing them together after 
dispersion. So, this results in a lack of central religious authority that keeps the essence of religion and crystallizes its concepts and standards.

Several secular comprehensive ideologies have succeeded in penetrating and grabbing Judaism from inside. Zionism is one of these ideologies that have succeeded in sneaking to Judaism. Jews in Palestine and Diasporas start to believe that Zionism can fulfill their dreams of forming their own "Jewish state". So, they neglect Judaism for the sake of having "a home" in land of Palestine. Ha'am himself noted the importance of the secular part of Judaism and its integration with Zionism. On this basis, he asked his peers to see the spiritual and secular sides of Judaism that created the individuality of Jews in his essay 'spiritual revival':

Language, literature, and religion, all renewed its [Judaism] youth; and each helped to reveal the inner spirit of Judaism through the medium of the new spiritual possession. To such an extent did this new spirit become identified with the Hebrew individuality that the thinkers of the period could not believe that it was foreign to them, and that Israel could ever have existed without it. (119)

In the beginning of the twentieth century, literature asserted the parity between Zionism and Judaism, and it emphasized many stories about Jews or Zionists, who were capable of 'making miracles'. In Exodus and The Haj, Uris confirms his theory of Zionism and its integration with Judaism. In many dialogues, he mentions the word 'Zionist' instead of Jews, "The Zionists are very clever people. For twenty-five years they have made us the villains in Palestine. They write words into the mandate articles and the Balfour Declaration that were never meant." (Exodus 13) In The Haj, he declares:

The Jews, we Zionists,' he said, 'will never be able to settle more than a few million people here. That is 
reality. What is also reality is the fact that such a state will always be surrounded by tens of millions of hostile Arabs. (The Haj 95)

Many people all over the world believe that Zionism and Judaism constitute one identical thing, though they are entirely two different philosophies. While Judaism is a divinely inspired religion, Zionism is a political movement. Judaism is the expression of the mutual relationship between God and the children of Israel, and it is one of the three divinely inspired religions, whose traditions and decrees seek peace and integration of Jews in every country where they exist. On the other hand, Zionism is a political and cultural movement that advocates 'the return of Jews' to the 'Promised Land'. According to many Zionist critics, Zionism is a form of nationalism of Jews, Jewish culture, religious renewal and liberation that support a Jewish nation state in the land of Palestine, as Ratsabi claims:

The future of Zionism depends only and solely on the chances for religious renewal. Secularism is like every destruction, liberation and risk. Thus, Zionism is no more than a liberation movement with a calculated risk that had caused the destruction of the reality of exile, and that fulfillment of its role in the re-entry of the Jews to history.

In his novels, Uris is ready to go beyond the main principles of cultural Zionism to persuasively associate the founding of Israel with forces of democracy in the world.

Cultural Zionists and Jewish nationalists were aware of the value and importance of publicity when it comes to the benefits of Zionism. Through this basis, Uris manages to extract a vital feature out of the principles of cultural Zionism that can facilitate protecting the Zionist entity of Israel; this principle is the Americanization of Israel. 
When Exodus was published, the state of Israel was twelve years old and the Holocaust was over. However, anti-Semitism was still prevailing in the United States of America, and Israel was still in desperate need of political, military, cultural, and social support. Some Americans felt a special connection to Israel and were compelled to advocate the idea of the nobility of Zionism. The movement has promoted and supported the 'return' of the Jewish people to what they have claimed to be their historic and biblical homeland in the 'Holy Land of Israel'. In many ways, Israel and the 'New Israeli-Jews' have resembled America and Americans, because they have represented a westernized system, democratic government, biblical history and political goals similar to America and Americans. Podhoretz, an American critic, analyzes the sensitive relation between America and Israel:

The special relationship Israel has with its biggest (and many times, it's only) ally, the United States, can be seen from Israel's early years to the present day. American-Israeli relations are in many ways unique. Both countries are nations of immigrants, places of refuge seen by many people as 'promised lands'. Since the establishment of the state of Israel, the United States has expressed its commitment to Israel's security and wellbeing and has devoted a considerable share of its worldwide economic and security assistance to Israel.

In Exodus and The Haj, Uris uses Joshua's story to justify Jews' presence in the land of Palestine, and he tries to discover common aspects between Americans and Israelis. Back to the seventeenth century, American puritans used the same story of Joshua as an excuse to justify the genocide of millions of Red Indians in America. On this basis, Palestinians have been likened to the Red Indians that should be exterminated to 
enable immigrant Jews to control 'the Promised Land', and turn it into a 'civilized nation'. Many American critics have tried to explain the story of Joshua to show the identical cases of America and Israel, by finding similarities between 'the Promised Land' and the New World (America). Also, they have arbitrarily tried to find Joshua embodied in Ben Gurion and George Washington, as Cherry explains:

The Pilgrims identified themselves with the ancient Hebrews. They viewed the New World and the New Canaan. They were God's chosen people headed for the Promised Land. Other colonists believed they, too, had been divinely called. The settlers in Virginia were, John Rolf said, "a peculiar people, marked and chosen by the finger of God." This self-image of being God's Chosen People called to establish the New Israel became an integral theme in America's self-interpretation. (43)

Taking into consideration the identical conditions of Jewish and American histories, Uris draws considerable similarities between Americans and Jews and refers to the story of Joshua in the novels to assert the idea of the 'New World' and the 'Promised Land' by declaring, "Here Joshua made the sun stand still!" At night the Bible was read to the exhausted warriors as a source of inspiration for the superhuman efforts the next day would call forth." (Exodus 512)

On the same wavelength, Uris underlines similarities between Palestinians and Red Indians and comes to the conclusion that they both should be eliminated to give enough space for 'superior powers' and modern technologies. In American culture, Red Indians and Arabs have been negatively depicted as superstitious, villains and subhumans. Arabs, according to Uris, are 'thieves' that have stolen the Promised Land from Jews. 
The idea of Americanization has been initially rejected by many Jewish critics, because of their fear of American hegemony that can erase Jewish culture. In the early stages of cultural Zionism, Ha'am opposed the process of Americanization. He expresses his fears of uprooting the fundamental traditions and culture of Jews, replacing them with American ones. He warns American Jews against forgetting their Hebrew culture and losing their identity. He expresses his fears of forgetting their language, stating:

The younger generation, born in America and educated in American schools, speaks English and does not understand Hebrew. If not for the yearly inrush of Hebrew speaking immigrants, there would not be a vestige of the language left in the New World. (282)

The process of Americanization has created a mixture of different values, thoughts and principles. As a result, America and Israel agree on new values that can be fulfilled, like: 'the American Dream' and the 'Promised Land'. These two concepts have united, to a great extent, American and Israeli's thoughts and goals and have made America a destination for people seeking freedom and individuality. In turn, Israel has represented a new version of America that can accommodate different types of people.

Exodus, a Zionist propaganda as claimed, was published when American interest in Israel was slight. Therefore, it is astonishing that a common American can read a Zionist epic telling the story of the establishment of Israel. Through Exodus, Uris transfers the events of the Middle East and his adventures to his American readers. Its storyline serves as an effective propaganda to counter continuing questioning of Israel's presence and promote pro-Jewish and pro-Israeli philosophies. Though its storyline is not balanced with positive and negative types of Jews and Arabs, Exodus is an apparent example of pro-Jewish novel. Its basic theme emphasizes the conditions of Jews and their need to 
live with dignity and pride in the newly-born state. Thus, the fundamental object of Exodus is to adopt the main goals of cultural Zionism and to gain national support for Israel.

As preconceptions and stereotypes about Jews have turned from unfamiliar figures and conceptions into legal citizens and positive ideas, immigrants Jews have found methods to merge into American society in shape, actions and culture. Starting from1920s, the doctrine of Americanization through assimilation and acculturation has been a promoted value in American life, and this has been reflected in American literature. Jews have begun to be re-introduced into novels after WWII; however, their portrayed images have not been that of diverse ethnic characters. Certain words, such as: Jewish, ethnic, and Jewish rituals have been kept off the novels and been replaced by American classic words, such as: individuality, freedom and citizenship. Several fictional and non-fictional characters in Exodus and The Haj reflect this new societal objective.

In Exodus, Jewish characters are paid much attention; however, their Jewishness is neutral and American-like characteristics are excessively emphasized. The protagonist, Ari Ben Canaan a native-born Israeli with no typical Jewish features, serves the American ideals. Ari is portrayed as very 'American' in appearance, behavior and culture. Uris describes him as a fantastically gorgeous man, well-built in his thirties, with black hair and dreamy blue eyes. The stereotype of Jews as weak and unattractive is challenged by Ari's good look:

Ari Ben Canaan, thirty, and a strapping six-footer with black hair and ice-blue eyes, could be mistaken for a movie leading man. He expressed his gratitude to wellwishers around the world and assured me the children were holding up fine. (Exodus 187) 
To symbolize the American-Israeli relationship, Uris portrays the American nurse,

Kitty Fremont as a kind and compassionate female figure who is clearly proud to be American. She is employed to show Israel as a substantial homeland for Jews and a welcoming place for all Americans. She is a good-looking, blond woman in her early thirties that severely suffers from the death of her husband, who was killed while serving as a reporter in Palestine. In World War II, many Americans lost their beloved ones due to wars, so Kitty's loss and sadness are easily used to emotionally affect American readers. Similar to the values of many Americans in the 1960 s, Kitty considers herself to be a kind-hearted liberal American who does not practice discrimination against any race: "Katherine Fremont. She was one of those great American traditions like Mom's apple pie, hot dogs, and the Brooklyn Dodgers. For Kitty Fremont was the proverbial "girl next door." (Exodus 2)

Throughout Exodus, Kitty is slowly transformed from an anti-Semite person who dedicates her life to her job to a more tolerant person, who learns to accept differences. In order to win the sympathy of American audience for Jews, Kitty forms two important relationships with Karen Hansen Clement and Ari Ben Canaan. Kitty first meets Karen in the detention camps in Cyprus, and she notices Karen's internal and external beauty through her compassionate care for Jewish children. Kitty begins to love Karen as her own daughter and even offers to adopt her.

Also, Kitty establishes a relationship with Ari Ben-Canaan and through their interactions; many Americans begin to learn about the history of Jews and their aspirations. Ari and Kitty's passion for each other represents the relationship between America and Israel. They draw a positive portrait of the mutual benefits between America 
and Israel. Their love story becomes a symbol of American-Israeli relationship that serves as a symbol of Americanization. According to Prell:

Love served...as a powerful symbol of Americanization because it revealed the reordering of the most fundamental principles of European Jewish life. In other words, this generation chose to place love and romance as a higher priority than their immigrant parents. Further, by employing a romance between members of different faiths and cultures, Leon Uris fits into the relevant theme of assimilation through love and the controversy over intermarriage surrounding many of America's minority groups." (70-71)

Though Ari is a typical Jewish figure in Exodus, Gideon Asch crystallizes this similarity in The Haj. Like Ari, Gideon has no personal life, because he lives in a kibbutz, Shemesh. Uris portrays Gideon, 'the desert rat', as a superhero who works as a spy for a long time among Arab tribes. He is fully aware of Arabic, Arab history and traditions, and he is a highly civilized, good-looking man with 'a neat blond beard and blue eyes.' In 1929, Gideon came to establish a small settlement in Tabah, because he aspired for living in peace among his 'hostile' Arab neighbors:

Asch was born a desert rat, able to disappear among the Bedouin and sink deeply into the vast brooding reaches of the wilderness of Zin and Paran, where Moses and the Hebrew Tribes had wandered for forty biblical years. He followed those routes of the Bible through the parched dry beds, piecing bits and clues together of how one can survive and travel in such a landscape. (The Haj 37)

If the characters of Exodus directly show their deep connection to the process of Americanization, those in The Haj are completely different. Uris represents the consequences of being away from the process of Americanization through three main 
Arab characters in The Haj: Haj Ibrahim, Ishmael and Nada. Haj Ibrahim, the muktar of Tabah attempts to integrate with the Jewish society in Palestine, unaware of the sacrifices he has to make like, subordinating Arab identity and ignoring their rights. Such great issues and sacrifices are ignored by Uris who believes that the major problem of Arabs seeking integration into Jewish society stems from other surrounding Arabs. However, Haj Ibrahim is not allowed to be assimilated into the 'civilized state of Israel', because he remains inferior, wild, deceitful and unequal to Jews:

My father [lbrahim] was only a young man, in his early twenties, when he declared himself muktar, 'the elected one.' His father had been muktar and when he died there was to be a new election. The sheiks of the other four clans had agreed that the eldest among them would take over the position. However, my father disagreed and the story of his courage and greatness has been told many, many times (The Haj 16)

Unlike his father, Ishmael admires Jewish and American values that have brought civilization and prosperity to his own village. Throughout Ishmael's voice that turns out to be an omniscient third person voice, Uris attacks all Arabs condemning them as decadent people. Ishmael's family is self-divided; his brothers cheat and blackmail their illiterate father. The tribal spirit is one of the elements that make Ishmael unable to reconcile himself with his family, society and traditions. As a result of his deep connection to Gideon, Ishmael denies the rules of Islam along with its instructions:

Take the case of my father, Ibrahim, becoming the Muktar of Tabah. In our world the repetition of stories is a way of life. Everyone eventually knows all of the tales of the past. (The Haj 7) 
Following the steps of her brother, Nada resents living in Arab society with its old, stiff and solid traditions. Her father used to treat her as a piece of furniture; she is supposed to obey and work without choosing any issue in her life. She becomes a prostitute when joining a fidayeen unit, and she willingly advocates prostitution as a form of rebellion against her oppressive father. As a result of her rebellion, Nada is brutally killed by her father for violating the moral codes of Arab society. She complains to Ishmael:

I remember once in Taba I saw a little Jewish girl waiting for the bus on the highway with her parents. She carried a doll and she showed it to me. It was very pretty, but it could do nothing but open and shut its eyes and cry when it was hit on the back. I am that doll. 'Obey . . . work . . . what is joy! (The Haj 655)

This shows that the process of Americanization has fruitfully worked with Jews, because they have accepted the American values of freedom, democracy and individuality. On the other hand, it has negatively affected Arabs as the children who have revolted against their father due to these American values. By liquidating Ibrahim's family, a symbol of the Arab community in Palestine, Uris aims to evacuate the land of Palestine in order to be inhabited by Zionist settlers. According to him, in the civilized world of Jews there is no place for 'barbarians'. Even Ibrahim, the loyal friend of Jews who betrays his people to satisfy Jews must be expelled from the 'Promised Land'. Since Haj Ibrahim, the Muktar of Tabah, is originally a descendent of the 'decadent' Arab tribes; he cannot be assimilated into the civilized community of Jews. In this context, The Haj's narrative turns into a ritual foundation dramatizing the moment of the passing of an old way of life into a new cultural form of progress providing a pretext for dominating and controlling Arabs. 
It is clear that Exodus and The Haj have a positive effect on American audiences. Their story transformed the Jewish character from inferior into a more familiar one; a thing which helped decrease levels of anti-Semitic feelings and increase tolerance. Moreover, it enhanced American understanding and support for cultural Zionism. Thus, Uris succeeded in developing Ahad Ha'am's cultural Zionism. Ha'am considers Jewish literary works as the main revival spirit that can keep the essence of cultural Zionism from any penetration. For most cultural Zionists, preserving Jewish literary works from narrowness and decay can save the basic spirit of cultural Zionism.

\section{Primary Sources.}

Uris, Leon. The Haj. New York: Bantam Books, 1984.

Exodus. New York: Doubleday, 1958.

\section{Secondary Sources.}

Cherry, Conrad (ed.), God's New Israel: Religious Interpretations of American Destiny. Englewood Cliffs: Prentice Hall, Inc., 1971.

Ha'am, Ahad. Selected Essays by Ahad Ha'am. Leon Simon, Trans, Philadelphia, The Jewish Publication Society of America, 1912.

Masalha, Nur. Expulsion of the Palestinians: The concept of "Transfer" in Zionist Political Thought, 1882-1948. Institute for Palestine Studies, 1992.

Nietzsche, Friedrich, Trans. Helen Zimmern. Beyond Good and Evil: Prelude to a Philosophy of the Future. Dover Thrift Editions, 2003. 
Prell, Riv-Ellen. Fighting to Become Americans: Jews, Gender, and the Anxiety of Assimilation. Boston, Beacon Press, 1999.

Podhoretz, Norman. Israel and the United States: a Complex History. Commentary, 1998. Ratsabi, Shalom. Zionism and Judaism: The Radical Circle in Brith Shalom, 1925-1933. Volume 23 of Brill's Series in Jewish Studies, BRILL, 2002. 